\title{
Estimation of equilibrium combustion products of diesel-biodiesel fuel blends using the developed solving process for $\mathrm{C}_{n} \mathrm{H}_{m}$ and $\mathrm{C}_{\alpha} \mathrm{H}_{\beta} \mathrm{O}_{\gamma}$ fuel types
}

\author{
Melih Yildiz* and Bilge Albayrak Çeper \\ Erciyes University Faculty of Engineering, \\ Department of Mechanical Engineering, 38039 Kayseri, Turkey \\ Email: melihyildiz@erciyes.edu.tr; balbayrak@erciyes.edu.tr
}

\begin{abstract}
This study investigates the combustion products of diesel-biodiesel fuel blends by considering its chemical equilibrium state. In order to determine the equilibrium combustion products involving 10 species, a solving scheme which can be used for different fuel blends consisting of $\mathrm{C}_{n} \mathrm{H}_{m}$ and $\mathrm{C}_{\alpha} \mathrm{H}_{\beta} \mathrm{O}_{\gamma}$ generic structures was developed. The constituted solving scheme was then applied for four different mixtures which were diesel, 20 and $50 \%$ biodiesel additions (by volume), and 100\% biodiesel. The change in mole fraction of the fuels and their blends was determined as a function of temperature, pressure and equivalence ratio. Besides, mass-based combustion product rates of $\mathrm{CO}_{2}$, $\mathrm{CO}$ and NO for a unity of fuel mass were also investigated for different temperatures and equivalence ratios. The results show that the addition of biodiesel to diesel fuel does not have any significant effect on the change in the mole fraction of the combustion products. However, the addition of biodiesel reduces slightly the formation of $\mathrm{CO}$ and $\mathrm{NO}$, while $\mathrm{CO}_{2}$ shows a slightly increasing trend. In terms of mass-based combustion product rates, the biodiesel addition reduces the amount of $\mathrm{CO}_{2}, \mathrm{CO}$ and $\mathrm{NO}$ products because it increases the molecular weight of the fuel blends.
\end{abstract}

Keywords: Chemical equilibrium; combustion model; biodiesel; diesel.

\section{INTRODUCTION}

Combustion in power generating systems such as in internal combustion engines or gas turbines is a major source of emissions, soot, $\mathrm{CO}, \mathrm{CO}_{2}, \mathrm{NO}_{\mathrm{x}}$ and $\mathrm{HC}$. With the growing concern about environmental issues, more stringent emission legislations have been put into effect in many countries. In addition, although the reserve capacity of petroleum fuels has reached a low level, their use is still dominant in many systems generating power. These main reasons led researchers to study advanced combustion systems and alternative fuels. In this regard, biodiesel has received considerable attention as an alternative fuel to petroleum diesel due to its properties. The properties of biodiesel are close to diesel, however; it has also disadvantages which are higher viscosity, lower energy content, higher cloud point and pour point, higher nitrogen oxides (NOx) emissions, injector coking, engine compatibility, and higher engine wear [1]. Therefore, its direct use is limited to a diesel engine [2]. It is used more commonly in blended petroleum diesel. Diesel fuel when used as a base in a biodiesel blend can affect the blend's emission characteristics and performance of the internal combustion engine. Several studies have reported the change in emission and performance in regards to biodiesel effects. Can [3] investigated the combustion, emissions and performance characteristics by adding 5\% 
and $10 \%$ biodiesel to a diesel engine $[4,5]$. The results stated that the addition of biodiesel fuel did not cause any significant changes in $\mathrm{CO}$ emissions at the low and medium loads, while significant improvements up to $51 \%$ were found at full load. $\mathrm{CO}_{2}$ emissions for all engine loads slightly increased with the biodiesel addition. Moreover, NOx emissions increased up to $8.7 \%$ for all engine conditions. Azad et al. [6] performed experimental studies on a multi-cylinder diesel engine to compare emissions and performance characteristics using soybean and waste oil biodiesel fuels. They used two biodiesel fuels at different fractions (5 to $20 \%$ with $5 \%$ increments, and 50\%) with diesel fuels to investigate the effects of soybean and waste oil biodiesel fuels separately. They concluded that the reduction in emissions was different for both biodiesels, and waste oil biodiesel has better trends in terms of emissions with the increase of biodiesel fraction. However, NOx emissions of both types of biodiesels were obtained at higher levels than that of diesel fuel [7-9]. On the other hand, significant improvements in $\mathrm{CO}, \mathrm{CO}_{2}$ and $\mathrm{HC}$ emissions were obtained using both types of biodiesel. Ozsezen [10] suggested that the oxygen content of biodiesel fuels contributes a complete oxidation of fuel in locally fuelrich zones, which leads to a reduction of $\mathrm{CO}$ and $\mathrm{HC}$ emissions. On the other hand, this also influences the NOx formation due to high local temperatures. However, much of the literature presents inconsistent trends in emissions such as comparing Ref. [3] and Ref. [6] in terms of $\mathrm{CO}_{2}$ emissions. Moreover, Monyem and Gerpen [11] concluded that the differences in NOx emissions between diesel and the $20 \%$ biodiesel were not significant, while Imtenan [12] showed a higher level of NOx emissions resulting from the use of biodiesel compared to diesel fuel. The differences in results are due to the physical and combustion processes within an engine such as injection timing, fuel vaporization and ignition delay period [13-15]. Besides, the differences in chemical composition and structure of fuels affect the combustion process development, which lead to the alteration of performance and emissions of an engine [16]. Biodiesel fuels are composed of many different classes of saturated and unsaturated fatty acids [17] which constitute their thermo physical and chemical structure properties. Biodiesel combustion is often found difficult to model due to the diversity of its sources and complexity in molecular structure [18-22]. However, combustion model studies are required to optimize a blend used in thermodynamic systems and to better understand combustion development along with experimental studies. In this regard, many numerical studies in literature have presented the use of suitable biodiesel surrogates, methyl butanoate [23, 24], methyl crotonate [25], and methyl decanoate [26, 27]. These works are mostly about 1D and 3D CFD studies, including a combustion kinetic model which is controlled by the rate of reactions [28-32]. A chemical kinetic model requires a set of elementary reactions with their reaction rates. Although a chemical kinetic model is able to provide a reasonable solution in many cases, it also involves sophisticated combustion calculation which in turn, increases the computational time. On the other hand, chemical equilibrium is a good approximation for a combustion model when assuming that the burned gases are at a chemical equilibrium in a high temperature combustion process. Chemical equilibrium is a condition based on the second law of thermodynamics which is defined as the Gibbs function change equals to zero for a reaction at a given pressure and temperature [33]. Therefore, in a combustion reaction, burned gases react together to produce and remove each species at equal rates. This means that it does not give a net change in species composition, but to the rate of occurring species at a given condition [34].

Chemical equilibrium models developed for fuel are widely used in thermodynamic simulations of internal combustion engines [35, 36]. Many approaches were used in studies which present algorithms by considering a different number of chemical species. 
A simple model including only six species of the products; $\mathrm{CO}_{2}, \mathrm{H}_{2} \mathrm{O}, \mathrm{N}_{2}, \mathrm{O}_{2}, \mathrm{CO}, \mathrm{H}_{2}$, has been defined by Heywood [37]. Gonca [38] investigated the effects of steam injection on the equilibrium products of bio-fuels such as biodiesel and alcohols. In their study, various bio-fuels were evaluated depending on their steam by air ratio by means of a constituted solving schema based on chemical equilibrium. Abbe et al. [39]performed a numerical study to compare four biodiesel surrogates using a zero dimensional thermodynamic model involving a chemical equilibrium combustion model. Ust and Kayadelen [40] used a chemical equilibrium model. They used 10 species of combustion products to predict their equilibrium and thermodynamic properties in a $\mathrm{H}_{2} \mathrm{O}$ injected combustion system at various $\mathrm{H}_{2} \mathrm{O}$ rates. The $\mathrm{CO}$ and $\mathrm{H}_{2}$ formations in a lean mixture were neglected. They, therefore, constituted their equation systems for lean and rich mixtures separately. They employed the equilibrium constants obtained from the JANAF table and then used the Newton-Raphson method to solve the equation systems. Rakopoulos et al. [41] studied a two-zone model for combustion and emissions formation in a direct injection diesel engine. They adopted a chemical equilibrium scheme involving 11 species of combustion products for calculating the constituents in exhaust gases. Diotallevi [42] developed a multi-zone model of a diesel engine for NOx formation. A chemical equilibrium scheme was created by considering 10 species as combustion products. The created a non-linear system of equations which was calculated using an iterative method developed by the author using the Matlab program. Mourya and Roy [43] carried out a study on the combustion modelling of a diesel engine operating using jatropha biodiesel and diesel engine blends according to a chemical equilibrium algorithm. To solve their equations, they utilized the $\mathrm{C}$ program and Mathematica software developed by the authors. Kayadelen [44] introduced a new equilibrium combustion model for fuels involving $\mathrm{C}, \mathrm{H}, \mathrm{O}$ and $\mathrm{N}$ molecules to calculate the mole fractions of equilibrium combustion products consisting of 14 species in terms of their thermodynamic properties and adiabatic flame temperature. The solving process was constituted into two paths to differentiate between rich mixture and lean mixture combustion in which $\mathrm{CO}$ and $\mathrm{H}_{2}$ were neglected. Thereby, the constituted linear equation systems were solved using both Gauss-Seidel and Newton-Raphson methods.

The objective of this study is to compare the equilibrium combustion products of diesel, biodiesel and their blends in terms of their mole fractions. For this purpose, the solving schema of the combustion model based on a chemical equilibrium was developed for blends of the $\mathrm{C}_{n} \mathrm{H}_{m}$ and $\mathrm{C}_{\alpha} \mathrm{H}_{\beta} \mathrm{O}_{\gamma}$ generic structure representing any hydrocarbon and oxygenated fuel using the Newton method with finite difference approximations in the Matlab program. Therefore, $\mathrm{C}_{\mathrm{n}} \mathrm{H}_{m}$ and $\mathrm{C}_{\alpha} \mathrm{H}_{\beta} \mathrm{O}_{\gamma}$ were used for the diesel and biodiesel fuels, respectively. The superiority of the developed combustion model allows for it to be executed at different blend ratios of fuels and atom numbers of $\mathrm{C}, \mathrm{H}$ and $\mathrm{O}$ without separating the equation system for lean and rich mixture combustion.

\section{METHODS AND MATERIALS}

\section{Equilibrium Combustion Model}

In the analytical model developed, it is assumed that $\mathrm{C}_{n} \mathrm{H}_{m}$ and $\mathrm{C}_{\alpha} \mathrm{H}_{\beta} \mathrm{O}_{\gamma}$ represent diesel and biodiesel respectively, and air as an oxidant contains a mol of $\mathrm{O}_{2}$ and $3.773 \mathrm{~mol}$ of $\mathrm{N}_{2}$, considering all molecules except $\mathrm{O}_{2}$ to be $\mathrm{N}_{2}$. The combustion products were considered to consist of 10 species which are all assumed as ideal gases. The chemical equation which describes the combustion is expressed as Eq. (1): 


$$
\begin{gathered}
f r c \mathrm{C}_{n} \mathrm{H}_{m}+(1-f r c) \mathrm{C}_{\alpha} \mathrm{H}_{\beta} \mathrm{O}_{\gamma}+(\delta / \phi)\left(\mathrm{O}_{2}+3.773 \mathrm{~N}_{2}\right) \rightarrow \\
x_{1} \mathrm{CO} 2+x_{2} \mathrm{CO}+x_{3} \mathrm{H}_{2} \mathrm{O}+x_{4} \mathrm{H}_{2}+x_{5} \mathrm{O}_{2}+x_{6} \mathrm{~N}_{2}+x_{7} \mathrm{H}+x_{8} \mathrm{O}+x_{9} \mathrm{NO}+x_{10} \mathrm{OH}
\end{gathered}
$$

where $x_{1}-x_{10}$ denotes the number of moles for each product, $n, m, \alpha, \beta$ and $\gamma$ represent the atom numbers of carbon, hydrogen and oxygen in the fuels, frc is a fraction of diesel fuel, $\phi$ is the equivalence ratio, and $\delta$ is the stoichiometric molar air fuel ratio as given in Eq. (2),

$$
\delta=f r c\left(\mathrm{n}+\frac{\mathrm{m}}{4}\right)+(1-f r c)\left(\alpha+\frac{\beta}{4}-\frac{\gamma}{2}\right)
$$

By writing the C-H-O-N balances for Eq. (1), the first 4 equations are obtained as follows:

C balance:

H balance:

$$
f r c . n+(1-f r c) \cdot \alpha-\left(\mathrm{x}_{1}+\mathrm{x}_{2}\right)=0
$$

O balance:

$$
f r c . \mathrm{m}+(1-f r c) \cdot \beta-\left(2\left(\mathrm{x}_{3}+\mathrm{x}_{4}\right)+\mathrm{x}_{7}+\mathrm{x}_{10}\right)=0
$$

$$
(1-f r c) \cdot \gamma+2 \cdot\left(\frac{\delta}{\phi}\right)-\left(2\left(\mathrm{x}_{1}+\mathrm{x}_{5}\right)+\mathrm{x}_{2}+\mathrm{x}_{3}+\mathrm{x}_{8}+\mathrm{x}_{9}+\mathrm{x}_{10}\right)=0
$$

$\mathrm{N}$ balance:

$$
7.546 . \delta-\left(2 \mathrm{x}_{6}+\mathrm{x}_{9}\right)=0
$$

Chemical equilibrium is a state in which the forward and backward rate of reactions are equal to each other at a given temperature and pressure. This means that the chemical composition in a reaction does not change unless the temperature or the pressure of a mixture is changed. Therefore, to solve for the 10 unknown mole numbers of Eq. (1), six dissociation equations are employed following the chemical reactions at equilibrium with the equilibrium constants based on partial pressure.

$$
\begin{array}{cl}
1 / 2 \mathrm{H}_{2} \leftrightarrows \mathrm{H} & \mathrm{x}_{7}\left(\frac{\mathrm{P}}{\mathrm{x}_{4} \sum_{1}^{10} \mathrm{x}_{\mathrm{i}}}\right)^{1 / 2}-\mathrm{Kp}_{1}=0 \\
1 / 2 \mathrm{O}_{2} \leftrightarrows \mathrm{O} & \mathrm{x}_{8}\left(\frac{\mathrm{P}}{\mathrm{x}_{5} \sum_{1}^{10} \mathrm{x}_{\mathrm{i}}}\right)^{1 / 2}-\mathrm{Kp}_{2}=0 \\
1 / 2 \mathrm{H}_{2}+1 / 2 \mathrm{O}_{2} \leftrightarrows \mathrm{OH} & \frac{\mathrm{x}_{10}}{\left(\mathrm{x}_{5} \mathrm{x}_{4}\right)^{1 / 2}-\mathrm{Kp}_{3}=0} \\
1 / 2 \mathrm{~N}_{2}+1 / 2 \mathrm{O}_{2} \leftrightarrows \mathrm{NO} & \frac{\mathrm{x}_{9}}{\left(\mathrm{x}_{6} \mathrm{x}_{5}\right)^{1 / 2}-\mathrm{Kp}_{4}=0} \\
\mathrm{H}_{2}+1 / 2 \mathrm{O}_{2} \leftrightarrows \mathrm{H}_{2} \mathrm{O} & \frac{\mathrm{x}_{3}}{\mathrm{x}_{4}}\left(\frac{\mathrm{P}}{\mathrm{x}_{5} \sum_{1}^{10} \mathrm{x}_{\mathrm{i}}}\right)^{1 / 2}-\mathrm{Kp}_{5}=0 \\
\mathrm{CO}+1 / 2 \mathrm{O}_{2} \leftrightarrows \mathrm{CO}_{2} & \frac{\mathrm{x}_{1}}{\mathrm{x}_{2}}\left(\frac{\mathrm{P}}{\mathrm{x}_{5} \sum_{1}^{10} \mathrm{x}_{\mathrm{i}}}\right)^{1 / 2}-\mathrm{Kp}_{6}=0
\end{array}
$$

where $\mathrm{P}$ is pressure in atmosphere and $\mathrm{Kp}_{1}-\mathrm{Kp}_{6}$ are the equilibrium constants based on the partial equation for the reactions. $K p_{j}(j=1$ to 6$)$ values can be obtained from the 
functions depending on the temperature given by Olikara and Borman [45] and Natarajan [46] using the JANAF Thermochemical Tables. Yum [47] suggested that the function uses NASA 7 polynomials as given in equations from Burcat [48] which are used in this study as follows.

Denote, $j=1$ to 6 for the Eqs. (7.1-7.6)

$$
\operatorname{lnK} \mathrm{p}_{\mathrm{j}}=\mathrm{a}_{1}(1-\ln \mathrm{T})-\mathrm{a}_{2}\left(\frac{\mathrm{T}}{2}\right)-\mathrm{a}_{3}\left(\frac{\mathrm{T}^{2}}{6}\right)-\mathrm{a}_{4}\left(\frac{\mathrm{T}^{3}}{12}\right)-\mathrm{a}_{5}\left(\frac{\mathrm{T}^{4}}{20}\right)+\mathrm{a}_{6}\left(\frac{1}{\mathrm{~T}}\right)-\mathrm{a}_{7}
$$

where $a_{1}-a_{7}$ are the coefficients which are found in the study of Ref. [36], and $T$ is the temperature in $\mathrm{K}$.

Thus, the $K p_{\mathrm{j}}$ values are calculated depending on temperature. $\mathrm{Kp}$ value gives an indication as to whether a reaction is product-favored or reactant-favored. If a Kp value of a reaction is bigger than 1.0, the reaction is product-favored, and vice versa. Figure 1 shows the change in Kp values in the range of 1400-3000 K.

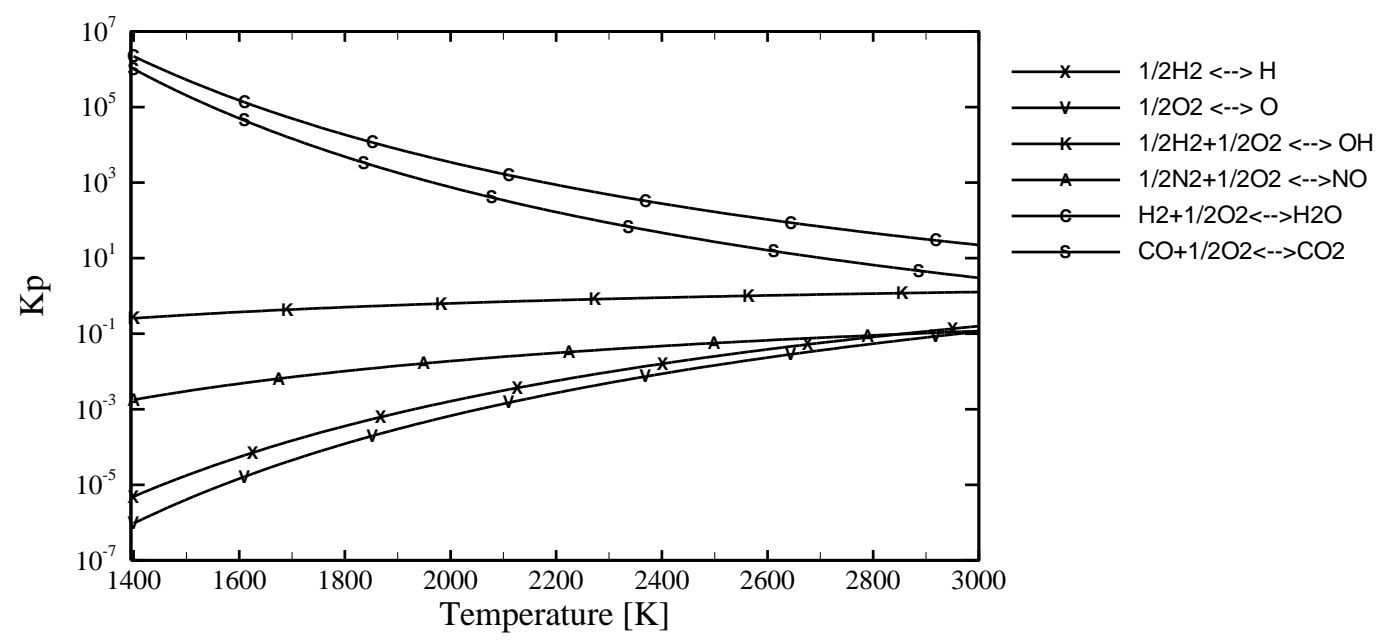

Figure 1. Change of Kp values with temperature.

After substituting Eq. (8) into Eqs. (7.1 -6) for each reaction, the algebraic equation system consisting of 10 equations is obtained to solve for the 10 unknowns, $\mathrm{x}_{1}-\mathrm{x}_{10}$. This equation system is non-linear due to the last 6 equations. To solve this equation system, Newton's method [49] was used as follows;

writing Eqs. (3-6) and Eqs. (7.1-6) in the form for 10 unknowns respectively; $\mathrm{i}=1: 10$;

$$
\begin{gathered}
f_{1}\left(x_{1}, x_{2}, \ldots, x_{i}\right)=0 \\
f_{2}\left(x_{1}, x_{2}, \ldots, x_{i}\right)=0 \\
\cdot \\
\cdot \\
\cdot \\
f_{i}\left(x_{1}, x_{2}, \ldots, x_{i}\right)=0
\end{gathered}
$$


vector for unknowns,

$$
x=\left[x_{1}, x_{2}, \ldots, x_{i}\right]^{T}(10)
$$

The initial guess for $\mathrm{x}$,

$$
x_{0}=\left[x_{1}^{0}, x_{2}^{0}, \ldots, x_{i}^{0},\right]^{T}
$$

The following expression yields for approximations to $\Delta \mathrm{x}_{\mathrm{i}}$,

$$
\left[\begin{array}{c}
f_{1}\left(x_{1}^{(0)}, x_{2}^{(0)}, \ldots, x_{i}^{(0)}\right) \\
f_{2}\left(x_{1}^{(0)}, x_{2}^{(0)}, \ldots, x_{i}^{(0)}\right) \\
\cdot \\
f_{i}\left(x_{1}^{(0)}, x_{2}^{(0)}, \ldots, x_{i}^{(0)}\right)
\end{array}\right]+\left[\begin{array}{c}
\frac{\partial f_{1}}{\partial x_{1}} \frac{\partial f_{1}}{\partial x_{2}} \ldots \frac{\partial f_{1}}{\partial x_{i}} \\
\frac{\partial f_{2}}{\partial x_{1}} \frac{\partial f_{2}}{\partial x_{2}} \ldots \frac{\partial f_{2}}{\partial x_{i}} \\
\frac{\partial f_{i}}{\partial x_{1}} \frac{\partial f_{i}}{\partial x_{2}} \ldots \frac{\partial f_{i}}{\partial x_{i}}
\end{array}\right] \cdot\left[\begin{array}{c}
d x_{1} \\
d x_{1} \\
\cdot \\
\cdot \\
\cdot \\
\cdot \\
d x_{i}
\end{array}\right] \cong 0
$$

The first fraction of the second term in Eq. (12) is a Jacobian matrix and was calculated using finite differences,

$(k=1$ to 10$)$

$$
\frac{\partial f_{i}}{\partial x_{k}} \approx \frac{f_{i}(x+\Gamma)-f_{i}(x)}{\Gamma}
$$

The value of $\Gamma$ was very close to zero to eliminate any truncation error. Thus, to solve for $\mathrm{dx}_{\mathrm{i}}$, the next iteration was calculated as follows;

$$
x_{i}^{i t e r}=x_{i}^{i t e r-1}+d x_{i}
$$

The iteration process ended when the solving process reached the desired converge criteria $\left(t_{1}\right.$ and $\left.t_{2}\right)$ as follows;

or

$$
\left|\left(x_{i}^{i t e r}-x_{i}^{i t e r+1}\right)\right|<t_{1}(15)
$$

$$
\left|\left(f_{i}^{i t e r}-f_{i}^{i t e r+1}\right)\right|<t_{2}(16)
$$

Thus, the moles of the equilibrium products were obtained in the solving scheme. This scheme was executed for both diesel and biodiesel fuels with typical chemical formulas of $\mathrm{C}_{14.09} \mathrm{H}_{24.78}$ and $\mathrm{C}_{18.74} \mathrm{H}_{34.43} \mathrm{O}_{2}$ [50], and mixtures of these fuels (Table 1) at different parameters as given in Table 2 .

Table 1. Fuel blends.

\begin{tabular}{ll}
\hline Fuel & Explanation \\
\hline D100 & 100\% Diesel \\
D80B20 & 80\% Diesel-20\%Biodiesel (mole fraction) \\
D50B50 & $50 \%$ Diesel-50\%Biodiesel (mole fraction) \\
B100 & 100\%Biodiesel \\
\hline
\end{tabular}


Table 2. Parameters for the solving process.

\begin{tabular}{ll}
\hline Variable & Range \\
\hline Temperature $(\mathrm{T})$ & $1400-3000 \mathrm{~K}$ (for a lean mixture) \\
& $1750-3000 \mathrm{~K}$ (for a rich mixture) \\
Pressure $(\mathrm{P})$ & $50 \mathrm{~atm}$ \\
Equivalence Ratio $(\phi)$ & $0.4-100 \mathrm{~atm}$ \\
\hline
\end{tabular}

After obtaining the solutions, the mole fraction and the amount of equilibrium combustion products per $\mathrm{kg}$ of fuel were calculated as follows;

$$
\begin{aligned}
& y x_{i}=\frac{x_{i}}{\sum_{1}^{i} x_{i}} \\
& m x_{i}=\frac{(M a)_{x_{i}}}{(M a)_{\text {fuel }}} * x_{i}\left[\frac{k g-x_{i}}{k g-f u e l}\right]
\end{aligned}
$$

where $(\mathrm{Ma})_{x i}$ and $(\mathrm{Ma})_{\text {fuel }}$ are the molecular weight of a combustion product and a fuel, respectively.

\section{RESULTS AND DISCUSSION}

The model was first applied for D100 and B100 under different equivalence ratios, temperature, and pressures according to Table 1 to determine how these parameters effect the change of mole fraction. Figure 2 shows the variation of equilibrium products with varying equivalence ratios at $2300 \mathrm{~K}$ and $50 \mathrm{~atm}$. The mixture is lean at an equivalence ratio of less than unity, and there is excess oxygen for complete combustion. Therefore, $\mathrm{CO}_{2}$ formation is at a high level for carbon-related reactions. When a mixture becomes stoichiometric and rich $(\phi \unrhd 1), \mathrm{CO}_{2}$ formation showed a decreasing trend, while $\mathrm{CO}$ increases due to the lack of oxygen for complete combustion [51]. This also causes $\mathrm{O}$, $\mathrm{OH}$, and $\mathrm{NO}$ to be reduced in the equilibrium combustion products. With a decrease of hydroxyl $(\mathrm{OH})$ formation, the atomic $\mathrm{H}$ increases, and some of them react with each other to produce $\mathrm{H}_{2}$ molecules.

The change of equilibrium products at varying temperatures are shown in Figures 3 and 4 for the lean and rich mixtures of D100 and B100 fuels. It can be seen in Figure 3 (for lean mixture) that $\mathrm{CO}_{2}, \mathrm{H}_{2} \mathrm{O}$ decreases slightly when temperature increases. The reason for this is that Reactions 7.5 and 7.6 became reactant-favored due to the decreasing values of $\mathrm{K}_{\mathrm{p}}$, as seen in Figure 1. Therefore, the increase of $\mathrm{CO}$ formation had stemmed from the decrease in $\mathrm{CO}_{2}$ for balancing the number of $\mathrm{C}$ atoms in the equation system. On the other hand, the increasing temperature enhanced the formation of other products (except $\mathrm{N}_{2}$ ) due to increases in $\mathrm{Kp}$ values related to the products. In a rich mixture as seen in Figure 3, $\mathrm{CO}$ and $\mathrm{H}_{2}$ are high, which are different from the levels shown in a lean mixture. This is evident when compared to trend in Figure 2. Besides, the increase in temperature had influenced the formation of products in the same manner as in a lean mixture due to changes in the equilibrium constants. 

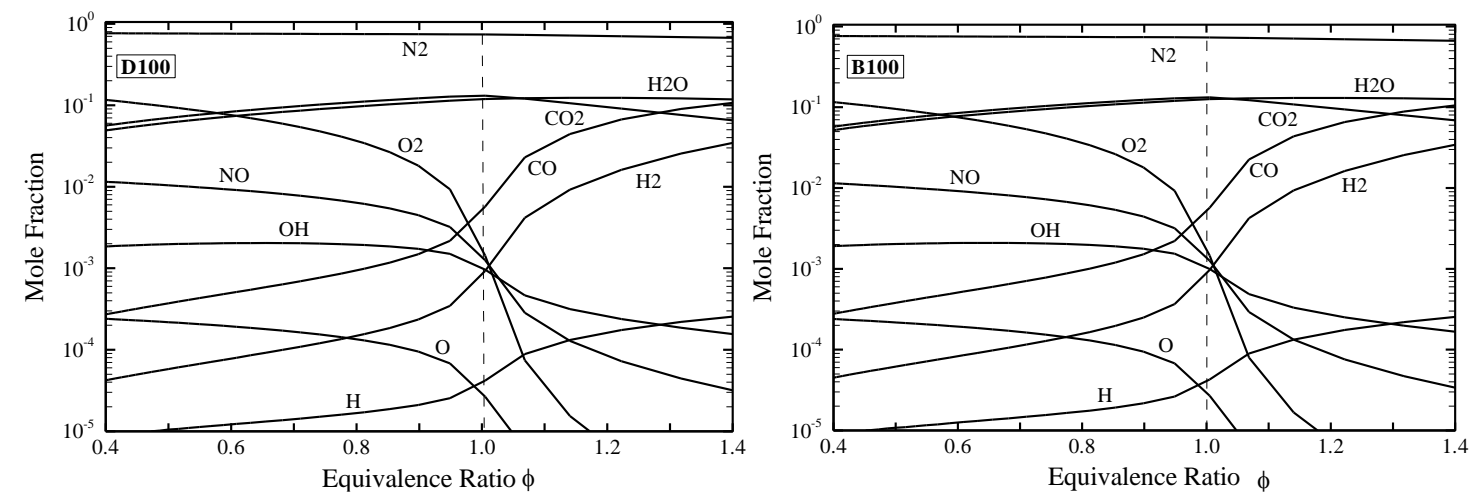

Figure 2. Mole fractions of combustion equilibrium products with varying equivalence ratios (at $2300 \mathrm{~K}$ and $50 \mathrm{Atm}$ ).
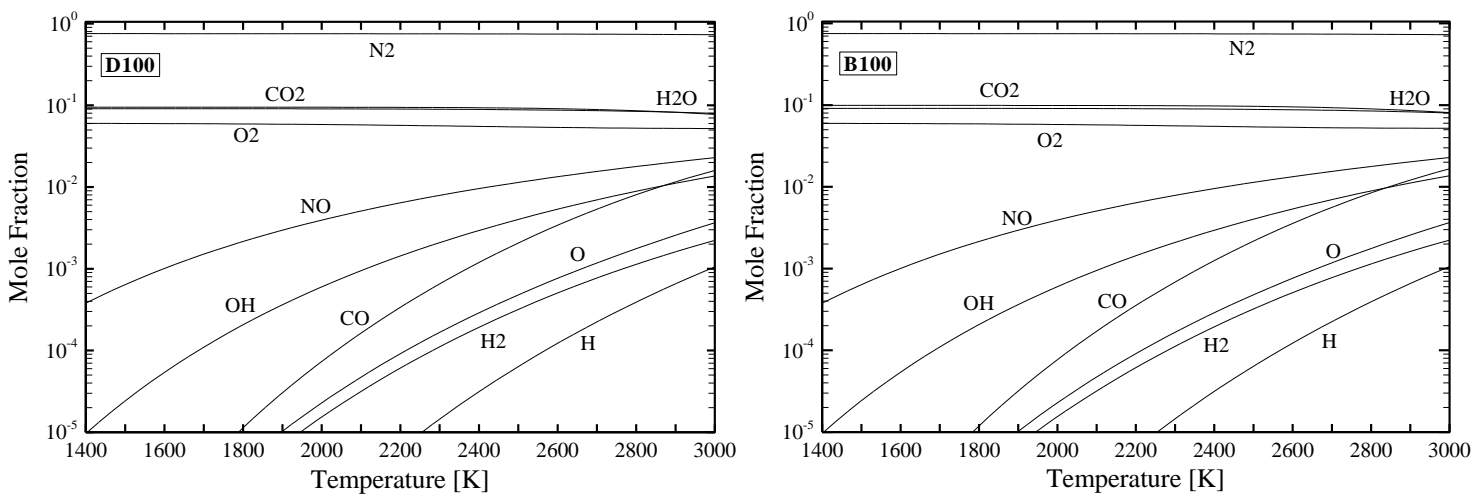

Figure 3. Mole fractions of combustion equilibrium products at varying temperatures (at $\phi=0.7$ and $50 \mathrm{Atm}$ ).
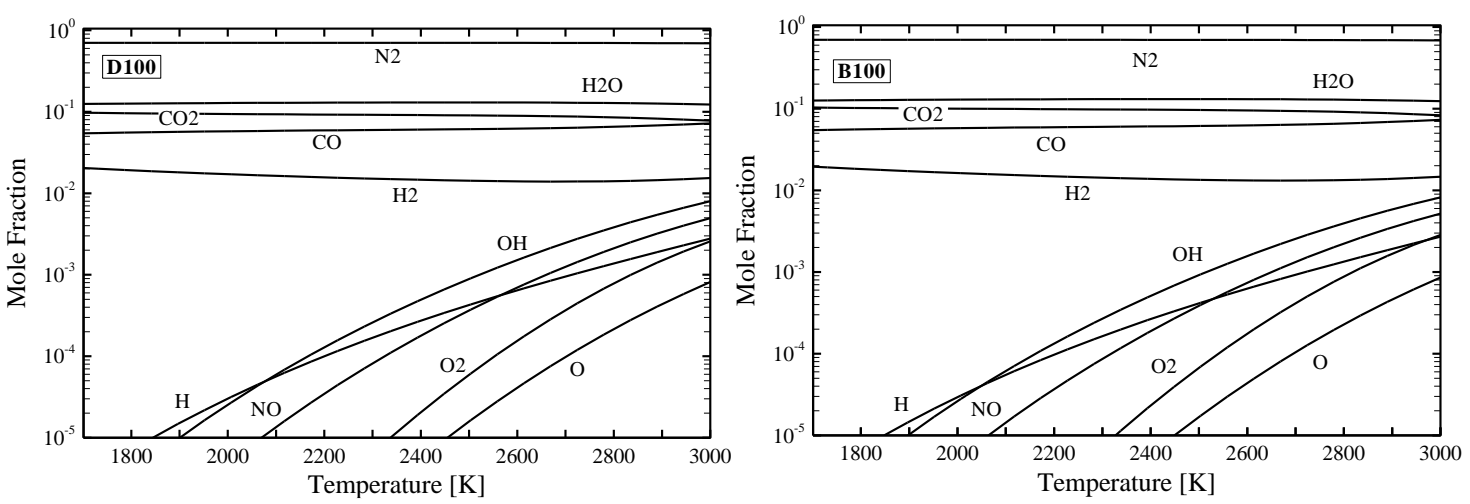

Figure 4. Mole fractions of combustion equilibrium products at varying temperatures (at $\phi=1.2$ and $50 \mathrm{Atm}$ ).

Figure 5 illustrates the mole fraction with changing pressures for the rich and lean mixtures of D100. With increasing pressure, the mole fraction of the equilibrium combustion products (except for $\mathrm{H}, \mathrm{NO}$ and $\mathrm{H}$ ) remained almost at a constant in a rich mixture, while the $\mathrm{H}_{2} \mathrm{O}, \mathrm{CO}_{2}, \mathrm{O}_{2}$, and $\mathrm{NO}$ products in the lean mixture are at levels as shown in Ref.[31,36]. By comparing previous results with those of the current study, it can be noted that $\mathrm{H}_{2} \mathrm{O}, \mathrm{CO}_{2}, \mathrm{CO}$ and $\mathrm{H}_{2}$ are the dominant products in a rich mixture, while $\mathrm{H}_{2} \mathrm{O}, \mathrm{CO} 2, \mathrm{O}_{2}$ and $\mathrm{NO}$ are dominant in a lean mixture. This implies that the partial 
pressure of these dominant products is higher than the others. Therefore, it can be suggested that the mole fractions of weak products had decreased due to the decrease in the ratio of partial pressure to total pressure [22].
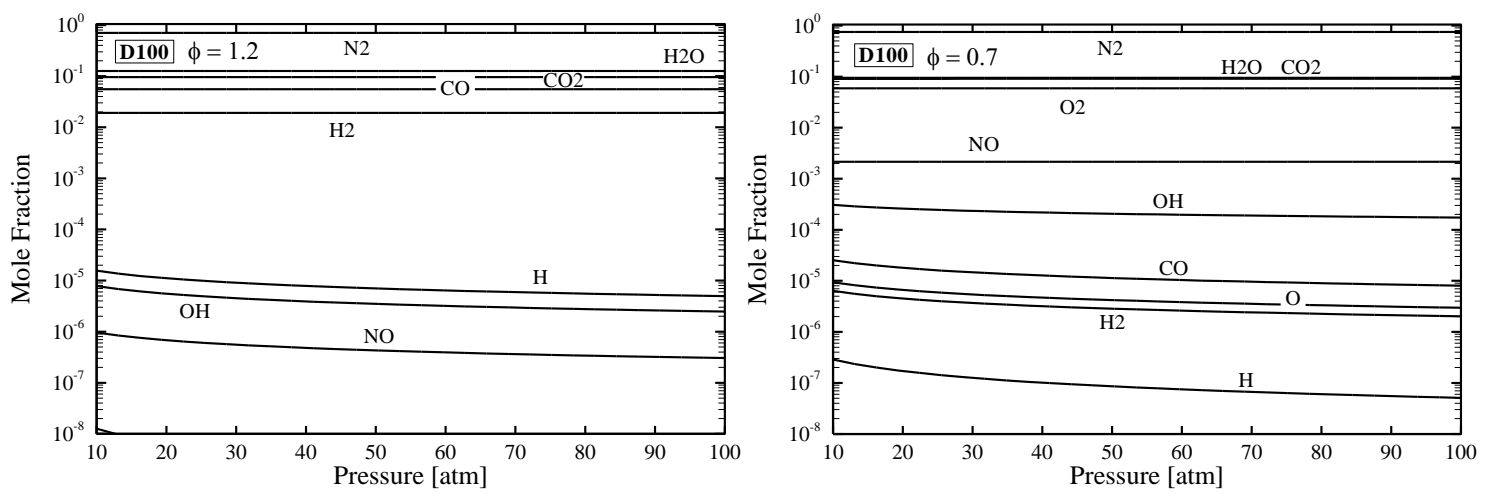

Figure 5. Mole fractions of combustion equilibrium products at varying pressures (at $1800 \mathrm{~K}$ ).

The solving process was also carried out for diesel and biodiesel fuel blends to compare their equilibrium combustion products, $\mathrm{CO}_{2}, \mathrm{CO}$ and $\mathrm{NO}$ which are the major pollutants in a combustion process. The fuel composition affects the composition of products due to the different stoichiometric air-fuel ratios and carbon/hydrogen ratios [51, 52]. Therefore, Figure 6 shows the products with changes in equivalence ratio for diesel, biodiesel, and their blends. When comparing the equilibrium products of each fuel, it can be seen that there are no considerable differences in the mole fractions for the fuels. The reason for this is that the carbon/hydrogen ratio of the fuels considered in this study varies from 0.57 to 0.55 , which are close values to each other $[53,54]$. However, when looking at Figure 6 in detail, in the case of the addition of biodiesel, $\mathrm{CO}$ and $\mathrm{NO}$ formations are lower than diesel, while $\mathrm{CO}_{2}$ formation is higher than that of $\mathrm{D} 100$ due to its $\mathrm{C}$ number. Atomic numbers of $\mathrm{N}$ and $\mathrm{O}$ play a key role in $\mathrm{NO}$ formation. As biodiesel includes $\mathrm{O}$ molecules, the required air for the reactions decreases, which in turn results in the number of $\mathrm{N}$ molecules produced in a combustion reaction to decrease [43]. Therefore, the mole fractions of NO were obtained at a lower level for D80B20, D50B50, B100.
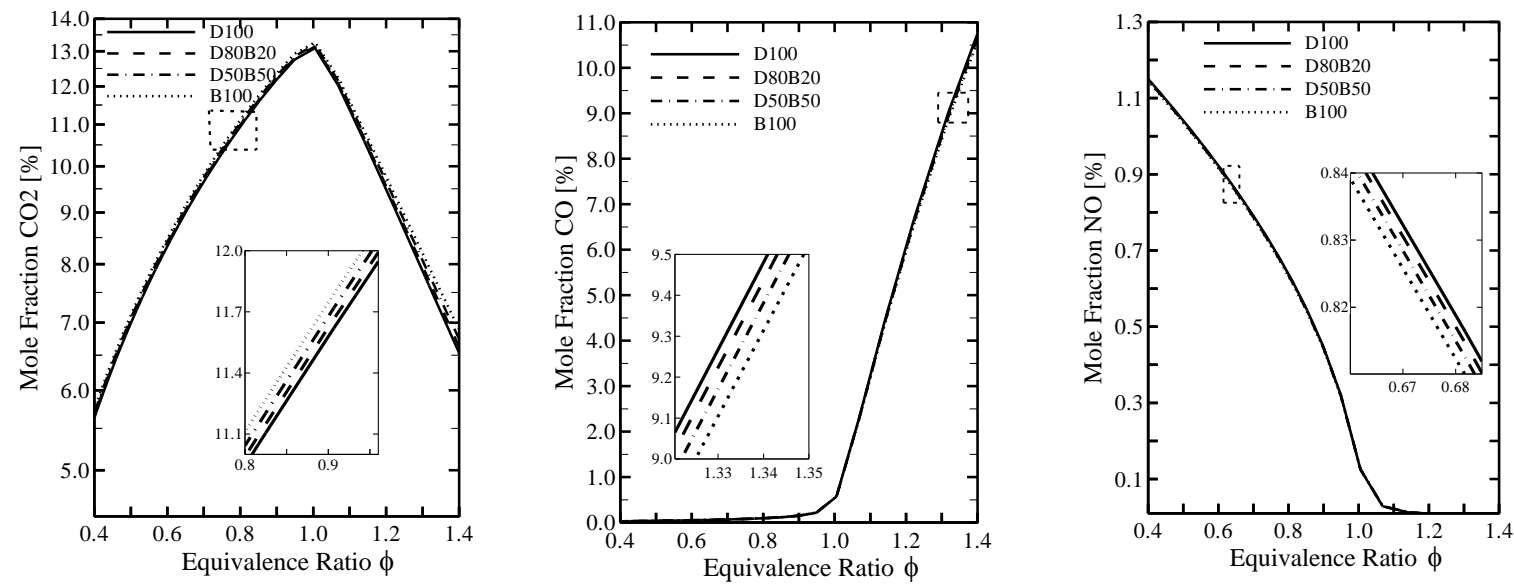

Figure 6. Comparison of combustion equilibrium products $\mathrm{CO} 2, \mathrm{CO}$ and $\mathrm{NO}$ for diesel and biodiesel blends at different equivalence ratios (at $2300 \mathrm{~K}$ and $50 \mathrm{Atm}$ ). 
Figure 7 demonstrates the equilibrium combustion products of the fuels at changing temperatures for a lean mixture. The $\mathrm{CO}_{2}$ formation of $\mathrm{B} 100$ is the highest among those of the fuels. In addition, the differences in $\mathrm{CO}_{2}$ mole fractions of the fuels decreases with increases in temperature. On the other hand, both the $\mathrm{CO}$ and NO levels of the fuels are nearly identical in terms of mole fraction because their fractions are already low in the combustion products relative to $\mathrm{CO}_{2}$. In general, the results based on Figures 6 and 7 can be attributed to the aforementioned reasons.
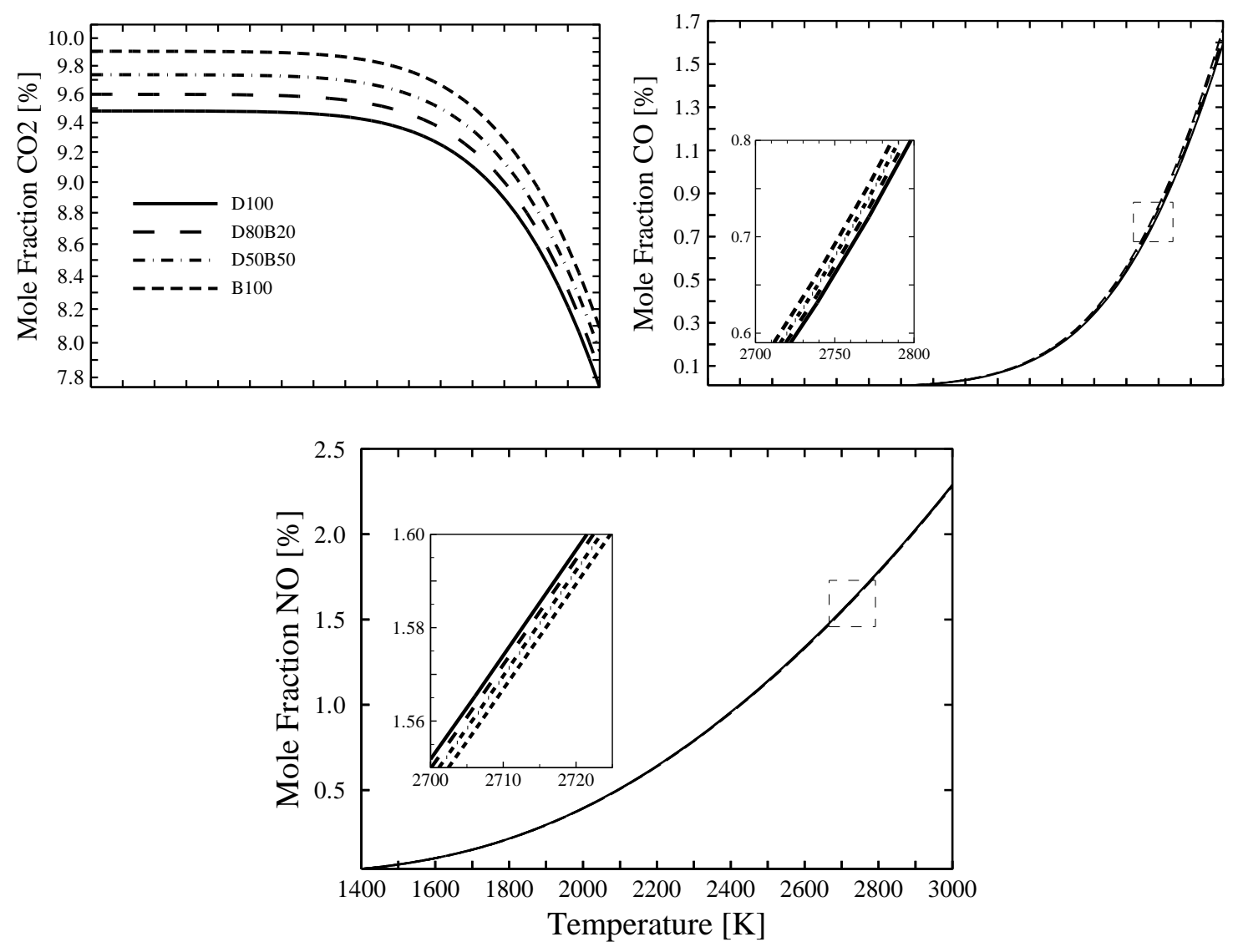

Figure 7. Comparison of combustion equilibrium products $\mathrm{CO}_{2}, \mathrm{CO}$ and $\mathrm{NO}$ for diesel and biodiesel blends at different temperatures $(\phi=0.7, P=50 \mathrm{~atm})$.

The emission rates of mass-based (produced) products for the unity of a fuel were calculated for different temperatures and equivalence ratios. Figures 8-10 show the variation of the equilibrium products $\mathrm{CO}_{2}, \mathrm{CO}$ and $\mathrm{NO}$ of the fuels. First, as seen in Figures 8 and 9 for $\mathrm{CO}_{2}$ and $\mathrm{CO}$, the characteristic curves are similar to each other and curves up to stoichiometric $(\phi \leq 1)$ by depending heavily on temperature, while they depend on the equivalence ratio in a rich mixture $(\phi>1)$. Considering the change in the amount of NO, which relies on both temperature and equivalence ratio. In general, it can be noted that the addition of biodiesel tends to decrease the amount of $\mathrm{CO}_{2}, \mathrm{CO}$ and $\mathrm{NO}[\mathrm{kg} / \mathrm{kg}$-fuel $]$ due to the fact that the molecular weight of biodiesel is heavier than that of diesel [55]. This means that the molecular weight of fuel increases with the addition of biodiesel, therefore; the amount of products per kilogram of fuel decreases (see Eq. 18). 
Estimation of equilibrium combustion products of diesel-biodiesel fuel blends using the developed solving process for $\mathrm{C}_{n} \mathrm{H}_{m}$ and $\mathrm{C}_{\alpha} \mathrm{H}_{\beta} \mathrm{O}_{\gamma}$ fuel blends
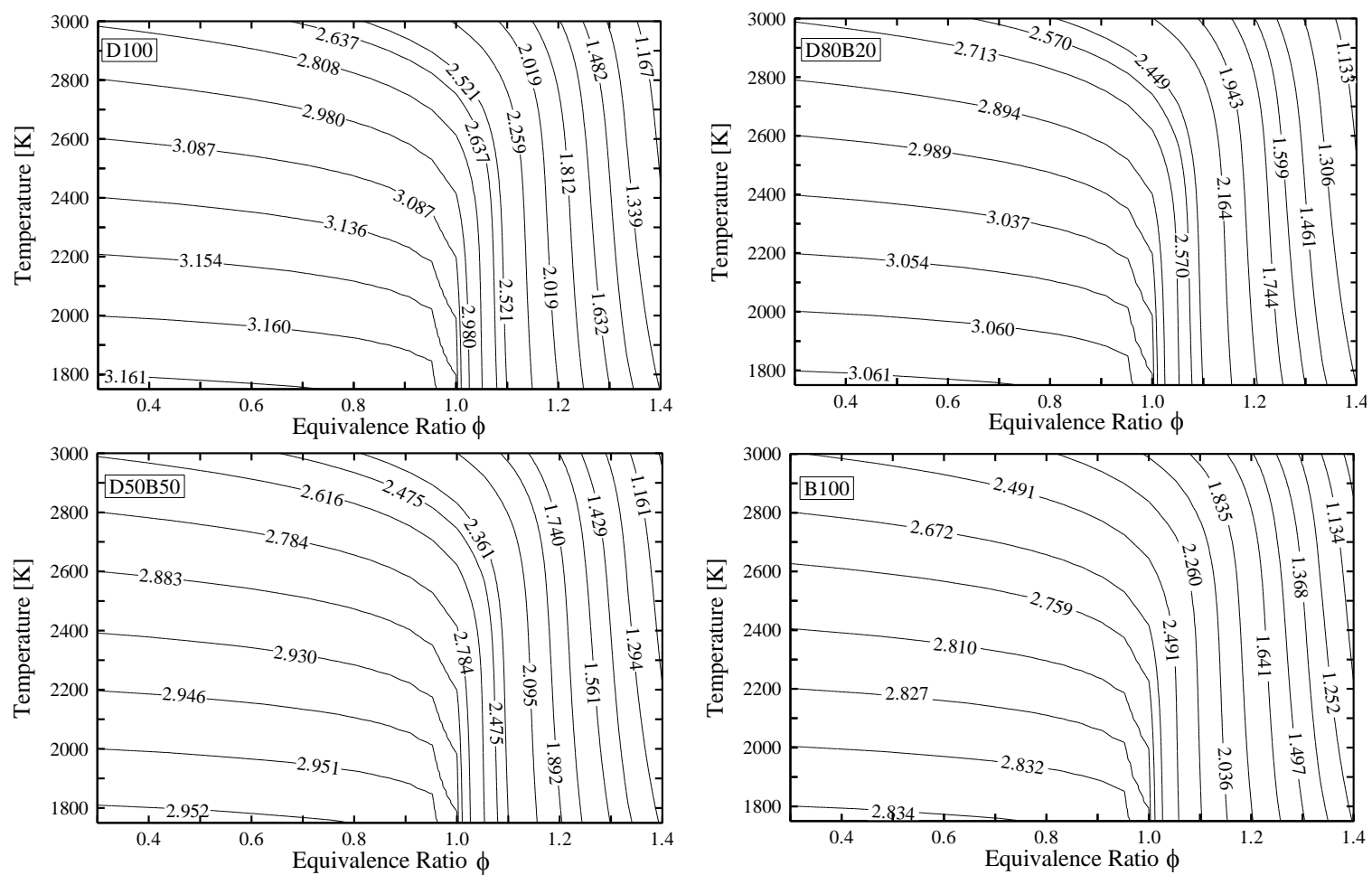

Figure 8. The amount of combustion equilibrium product $\mathrm{CO}_{2}[\mathrm{~kg} / \mathrm{kg}$-fuel $]$ for the fuel blends.
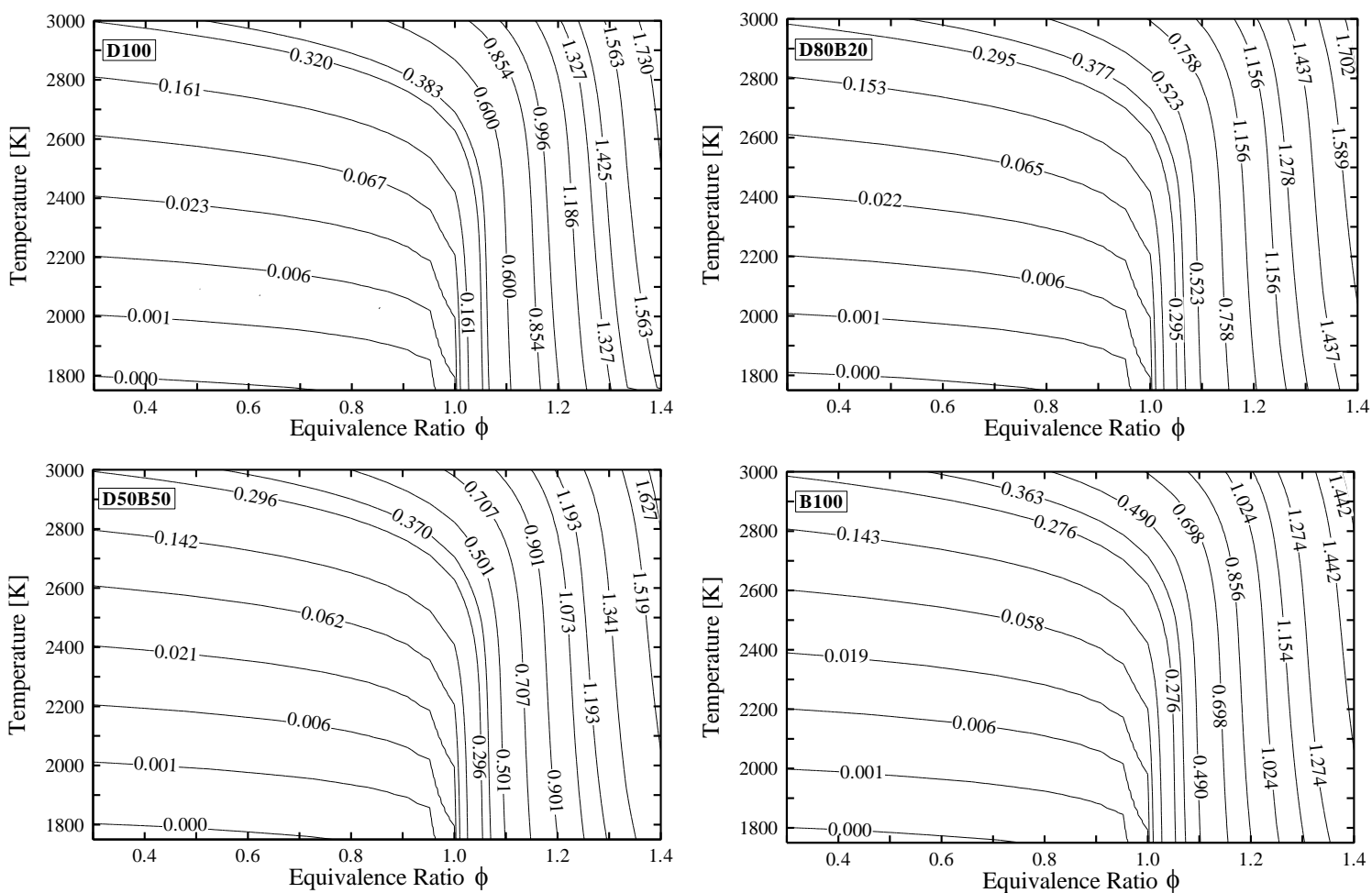

Figure 9. The amount of combustion equilibrium product $\mathrm{CO}[\mathrm{kg} / \mathrm{kg}$-fuel $]$ for the fuel blends. 

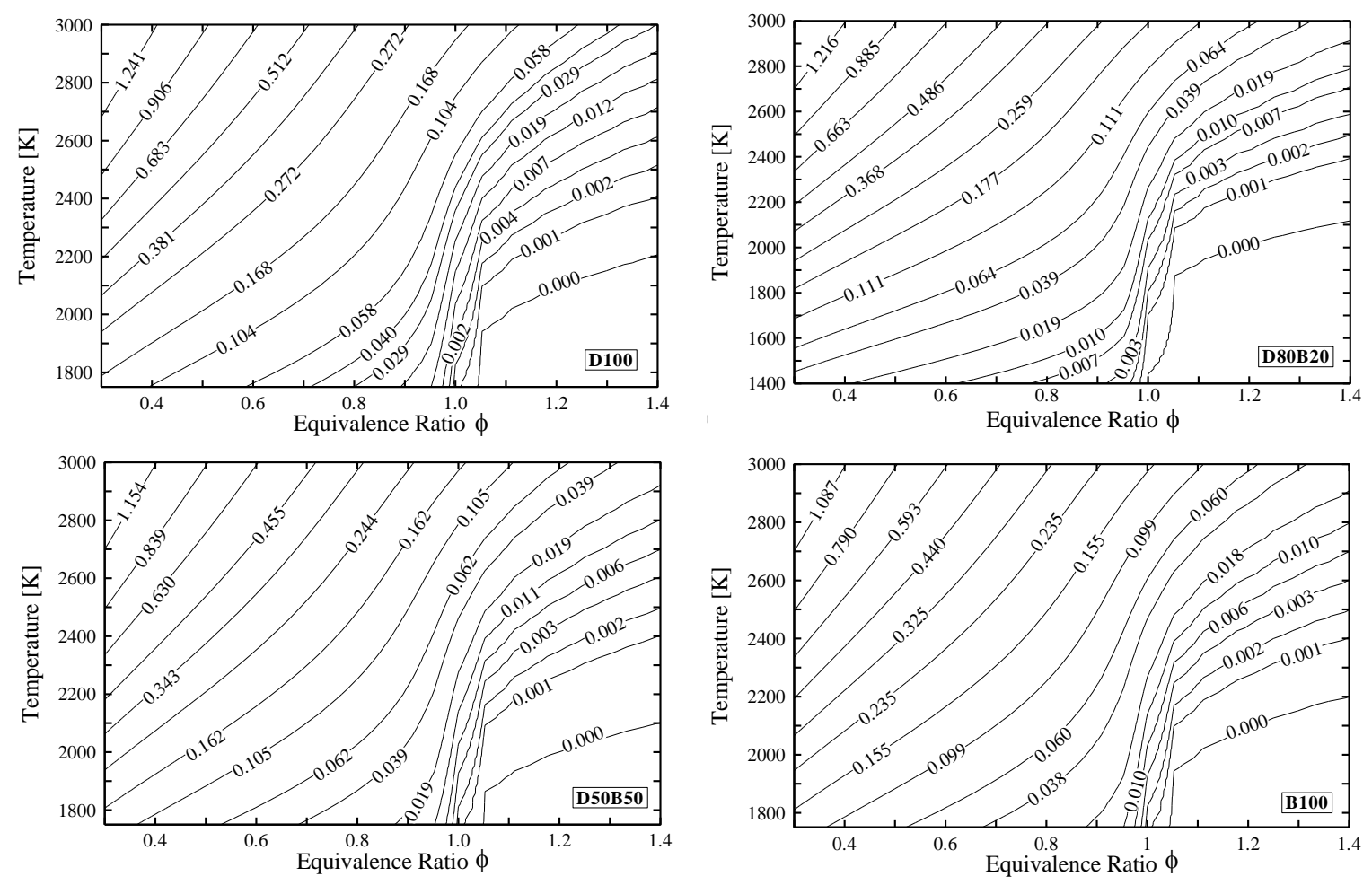

Figure 10. The amount of combustion equilibrium product NO [kg/kg-fuel $]$ for the fuel blends.

\section{CONCLUSIONS}

In this work, the effect of the addition of biodiesel to diesel-based fuel on its equilibrium products in terms of mole fraction was investigated using a combustion model based-on chemical equilibrium which can be used for $\mathrm{C}_{n} \mathrm{H}_{m}$ and $\mathrm{C}_{\alpha} \mathrm{H}_{\beta} \mathrm{O}_{\gamma}$ fuels and their blends. Four different fuels which are D100, D80B20, D50B50 and B100 were investigated for their equilibrium combustion products under different temperatures, pressures and equivalence ratios using the created solving schema which adopted the Newton method with finite differences approximation. The following conclusions can be stated:

i) Increases in the biodiesel fraction do not have any significant effect on the change of mole fractions of the equilibrium products due to its $\mathrm{C} / \mathrm{H}$ ratio which is close to diesel.

ii) The mole fractions of $\mathrm{CO}_{2}$ increase with the increase in biodiesel fraction due to the $\mathrm{O}$ content in biodiesel fuel which helps to complete combustion.

iii) In terms of mass-based formation, the amounts of $\mathrm{CO}_{2}, \mathrm{CO}$ and $\mathrm{NO}$ per $\mathrm{kg}$ fuel tend to decrease when the biodiesel fraction increases.

iv) $\mathrm{CO}_{2}$ and $\mathrm{HO}_{2}$ mole fractions have a slightly decreasing trend with increases in temperature because the $\mathrm{Kp}$ values of the related reactions decrease, making the reaction change to be reactant-favored.

The combustion model is independent of an engine modelling procedure, and it can be easily adapted to a thermodynamic-based engine simulation model for $\mathrm{C}_{n} \mathrm{H}_{m}$ and $\mathrm{C}_{\alpha} \mathrm{H}_{\beta} \mathrm{O}_{\gamma}$ fuels to estimate pollutant emissions and their thermodynamic properties. 


\section{ACKNOWLEDGEMENTS}

The authors would like to thank anonymous reviewers for their valuable comments to improve this work. The authors are also grateful to Erciyes University for providing opportunities.

\section{REFERENCES}

[1] Demirbas A. Importance of biodiesel as transportation fuel. Energy Policy. 2007;35:4661-70.

[2] Hoque N, Mourshed M, Das B. Performance and emission comparison of karanja (pongamia pinnata), pithraj (aphanamixis polystachya), neem (azadira chtaindica) and mahua (madhuca longofolia) seed oil as a potential feedstock for biodiesel production in Bangladesh. International Journal of Automotive and Mechanical Engineering. 2015;12:2967.

[3] Can Ö. Combustion characteristics, performance and exhaust emissions of a diesel engine fueled with a waste cooking oil biodiesel mixture. Energy Conversion and Management. 2014;87:676-86.

[4] Saifuddin N, Refal H, Kumaran P. Performance and emission characteristics of micro gas turbine engine fuelled with bioethanol-diesel-biodiesel blends. International Journal of Automotive and Mechanical Engineering. 2017;14:403049.

[5] Rostami S, Ghobadian B, Kiani Deh Kiani M. Effect of the injection timing on the performance of a diesel engine using diesel-biodiesel blends. International Journal of Automotive and Mechanical Engineering. 2014;10:1945-58.

[6] Azad AK, Rasul M, Giannangelo B, Islam R. Comparative study of diesel engine performance and emission with soybean and waste oil biodiesel fuels. International Journal of Automotive and Mechanical Engineering. 2015;12:2866.

[7] Mohd Noor CW, Mamat R, Najafi G, Mat Yasin MH, Ihsan CK, Noor MM. Prediction of marine diesel engine performance by using artificial neural network model. Journal of Mechanical Engineering and Sciences. 2016;10:1917-30.

[8] Yasin MHM, Mamat R, Aziz A, Yusop AF, Ali MH. Investigation on combustion parameters of palm biodiesel operating with a diesel engine. Journal of Mechanical Engineering and Sciences. 2015;9:1714-26.

[9] Said NH, Ani FN, Said MFM. Review of the production of biodiesel from waste cooking oil using solid catalysts. Journal of Mechanical Engineering and Sciences. 2015;8:1302-11.

[10] Ozsezen AN, Canakci M. Determination of performance and combustion characteristics of a diesel engine fueled with canola and waste palm oil methyl esters. Energy Conversion and Management. 2011;52:108-16.

[11] Monyem A, Van Gerpen JH. The effect of biodiesel oxidation on engine performance and emissions. Biomass and Bioenergy. 2001;20:317-25.

[12] Imtenan S, Masjuki H, Varman M, Kalam M, Arbab M, Sajjad H, et al. Impact of oxygenated additives to palm and jatropha biodiesel blends in the context of performance and emissions characteristics of a light-duty diesel engine. Energy Conversion and Management. 2014;83:149-58.

[13] Lapuerta M, Armas O, Rodriguez-Fernandez J. Effect of biodiesel fuels on diesel engine emissions. Progress in Energy and Combustion Science. 2008;34:198-223. 
[14] Sathiyamoorthi R, Sankaranarayanan G. Fuel injection timings of a direct injection diesel engine running on neat lemongrass oil-diesel blends. International Journal of Automotive and Mechanical Engineering. 2015;11:2348-63.

[15] Khalid A, Jaat N, Sapit A, Razali A, Manshoor B, Zaman I, et al. Performance and emissions characteristics of crude jatropha oil biodiesel blends in a diesel engine. International Journal of Automotive and Mechanical Engineering. 2015;11:2447-57.

[16] Hellier P, Talibi M, Eveleigh A, Ladommatos N. An overview of the effects of fuel molecular structure on the combustion and emissions characteristics of compression ignition engines. Proceedings of the Institution of Mechanical Engineers, Part D: Journal of Automobile Engineering. 2017:0954407016687453.

[17] Tamilselvan P, Nallusamy N, Rajkumar S. A comprehensive review on performance, combustion and emission characteristics of biodiesel fuelled diesel engines. Renewable and Sustainable Energy Reviews. 2017;79:1134-59.

[18] Coniglio L, Bennadji H, Glaude PA, Herbinet O, Billaud F. Combustion chemical kinetics of biodiesel and related compounds (methyl and ethyl esters): Experiments and modeling-advances and future refinements. Progress in Energy and Combustion Science. 2013;39:340-82.

[19] Visconti P, Primiceri P, Strafella L, Carlucci AP, Ficarella A. Morphological analysis of injected sprays of different bio-diesel fuels by using a common rail setup controlled by a programmable electronic system. International Journal of Automotive and Mechanical Engineering. 2017;14:3849-71.

[20] Nayak SK, Mishra PC. Emission from a dual fuel operated diesel engine fuelled with calophyllum inophyllum biodiesel and producer gas. International Journal of Automotive and Mechanical Engineering. 2017;14:3954-69.

[21] Shukri MR, Rahman MM, Ramasamy D, Kadirgama K. Artificial neural network optimization modeling on engine performance of diesel engine using biodiesel fuel. International Journal of Automotive and Mechanical Engineering. 2015;11:2332-47.

[22] Hasan MM, Rahman MM, Kadirgama K. A review on homogeneous charge compression ignition engine performance using biodiesel-diesel blend as a fuel. International Journal of Automotive and Mechanical Engineering. 2015;11:2199211.

[23] Ismail HM, Ng HK, Gan S, Lucchini T, Onorati A. Development of a reduced biodiesel combustion kinetics mechanism for cfd modelling of a light-duty diesel engine. Fuel. 2013;106:388-400.

[24] Um S, Park SW. Modeling effect of the biodiesel mixing ratio on combustion and emission characteristics using a reduced mechanism of methyl butanoate. Fuel. 2010;89:1415-21.

[25] Ng HK, Gan S, Ng J-H, Pang KM. Development and validation of a reduced combined biodiesel-diesel reaction mechanism. Fuel. 2013;104:620-34.

[26] An H, Yang W, Maghbouli A, Li J, Chua K. A skeletal mechanism for biodiesel blend surrogates combustion. Energy Conversion and Management. 2014;81:519.

[27] Luo Z, Plomer M, Lu T, Som S, Longman DE, Sarathy SM, et al. A reduced mechanism for biodiesel surrogates for compression ignition engine applications. Fuel. 2012;99:143-53.

[28] Hairuddin AA, Yusaf T, Wandel AP. Single-zone zero-dimensional model study for diesel-fuelled homogeneous charge compression ignition (HCCI) engines 
using cantera. International Journal of Automotive and Mechanical Engineering. 2016;13(2):3309-28.

[29] Colin O, da Cruz AP, Jay S. Detailed chemistry-based auto-ignition model including low temperature phenomena applied to 3-d engine calculations. Proceedings of the Combustion Institute. 2005;30:2649-56.

[30] Soyhan HS, Mauss F, Sorusbay C. Chemical kinetic modeling of combustion in internal combustion engines using reduced chemistry. Combustion Science and Technology. 2002;174:73-91.

[31] Sathiah P, Komen E, Roekaerts D. The role of cfd combustion modeling in hydrogen safety management-part i: Validation based on small scale experiments. Nuclear Engineering and Design. 2012;248:93-107.

[32] Chen R, Milovanovic N. A computational study into the effect of exhaust gas recycling on homogeneous charge compression ignition combustion in internal combustion engines fuelled with methane. International Journal of Thermal Sciences. 2002;41:805-13.

[33] Cengel YA, Boles MA. Thermodynamics: An engineering approach. Sea. 2002;1000:8862.

[34] Rashidi M. Calculation of equilibrium composition in combustion products. Chemical Engineering and Technology. 1997;20:571-5.

[35] Way R. Methods for determination of composition and thermodynamic properties of combustion products for internal combustion engine calculations. Proceedings of the Institution of Mechanical Engineers. 1976;190:687-97.

[36] Ramachandran S. Rapid thermodynamic simulation model of an internal combustion engine on alternate fuels. Proceedings of the International MultiConference of Engineers and Computer Scientists. 2009. p. 18-20.

[37] Heywood JB. Internal combustion engine fundamentals: Mcgraw-hill New York; 1988.

[38] Gonca G. Investigation of the influences of steam injection on the equilibrium combustion products and thermodynamic properties of bio fuels (biodiesels and alcohols). Fuel. 2015;144:244-58.

[39] Ngayihi Abbe CV, Danwe R, Nzengwa R. Comparative numerical study of four biodiesel surrogates for application on diesel OD phenomenological modeling. Journal of Combustion. 2016;2016.

[40] Kayadelen HK, Ust Y. Prediction of equilibrium products and thermodynamic properties in $\mathrm{H}_{2} \mathrm{O}$ injected combustion for $\mathrm{C}_{\alpha} \mathrm{H}_{\beta} \mathrm{O}_{\gamma} \mathrm{N}_{\delta}$ type fuels. Fuel. 2013;113:389-401.

[41] Rakopoulos C, Rakopoulos D, Kyritsis D. Development and validation of a comprehensive two-zone model for combustion and emissions formation in a di diesel engine. International Journal of Energy Research. 2003;27:1221-49.

[42] Diotallevi F. Development of a multi-zone model for nox formation in diesel engines. KTH Industrial Engineering and Management, Stockolm, Sweden. 2007.

[43] Mourya D, Roy V. Combustion modeling and simulation of combustion emissions for diesel engine operating on the blends of jatropha biodiesel and diesel. International Journal of Engineering Science and Technology. 2012;4(4):137381.

[44] Kayadelen HK. A multi-featured model for estimation of thermodynamic properties, adiabatic flame temperature and equilibrium combustion products of fuels, fuel blends, surrogates and fuel additives. Energy. 2018;143:241-56. 
[45] Olikara C, Borman GL. A computer program for calculating properties of equilibrium combustion products with some applications to IC engines. SAE Technical Paper; 1975.

[46] K.Natarajan. Computing equilibrium constants of chemical reactions- a new approach. International Journal of ChemTech Research. 2014-2015;7:2361-7.

[47] Yum KK. Modeling and simulation of transient performance and emission of diesel engine: Pseudo bond graph approach to modelling the thermodynamic process. Institutt for Marin Teknikk; 2012.

[48] Burcat A, Ruscic B. Third millenium ideal gas and condensed phase thermochemical database for combustion with updates from active thermochemical tables: Argonne National Laboratory Argonne, IL; 2005.

[49] Beers KJ. Numerical methods for chemical engineering: Applications in MATLAB: Cambridge University Press; 2006.

[50] Sun J, Caton JA, Jacobs TJ. Oxides of nitrogen emissions from biodiesel-fuelled diesel engines. Progress in Energy and Combustion Science. 2010;36:677-95.

[51] Baskar P, Senthilkumar A. Effects of oxygen enriched combustion on pollution and performance characteristics of a diesel engine. Engineering Science and Technology, an International Journal. 2016;19:438-43.

[52] Alrazen HA, Ahmad K. Hcng fueled spark-ignition (SI) engine with its effects on performance and emissions. Renewable and Sustainable Energy Reviews. 2018;82:324-42.

[53] Winterbone D, Turan A. Advanced thermodynamics for engineers: ButterworthHeinemann; 2015.

[54] Nayak S, Mishra P. Emission from a dual fuel operated diesel engine fuelled with calophyllum inophyllum biodiesel and producer gas. International Journal of Automotive and Mechanical Engineering. 2017;14(1):3954-78.

[55] Rakopoulos C, Antonopoulos K, Rakopoulos D. Development and application of multi-zone model for combustion and pollutants formation in direct injection diesel engine running with vegetable oil or its bio-diesel. Energy Conversion and Management. 2007;48:1881-901. 